\title{
Effects of Semiarid Wheat Agriculture Management Practices on Soil Microbial Properties: A Review
}

\author{
Hannah R. Rodgers * $\mathbb{D}$, Jay B. Norton and Linda T.A. van Diepen \\ Department of Ecosystem Science \& Management, University of Wyoming, Laramie, WY 82071, USA; \\ jnorton4@uwyo.edu (J.B.N.); lvandiep@uwyo.edu (L.T.A.v.D.) \\ * Correspondence: hrodger3@uwyo.edu
}

Citation: Rodgers, H.R.; Norton, J.B.; van Diepen, L.T.A. Effects of Semiarid Wheat Agriculture Management Practices on Soil Microbial Properties: A Review. Agronomy 2021, 11, 852. https://doi.org/10.3390/ agronomy11050852

Academic Editor:

Nikolaos Monokrousos

Received: 1 April 2021

Accepted: 24 April 2021

Published: 27 April 2021

Publisher's Note: MDPI stays neutral with regard to jurisdictional claims in published maps and institutional affiliations.

Copyright: (c) 2021 by the authors. Licensee MDPI, Basel, Switzerland. This article is an open access article distributed under the terms and conditions of the Creative Commons Attribution (CC BY) license (https:// creativecommons.org/licenses/by/ $4.0 /)$.

\begin{abstract}
Agricultural management decisions on factors such as tillage, fertilization, and cropping system determine the fate of much of the world's soils, and soil microbes both mediate and respond to these changes. However, relationships between management practices and soil microbial properties are poorly understood, especially in semiarid regions. To address this knowledge gap, we reviewed research papers published between 2000 and 2020 that analyzed soil microorganisms in semiarid wheat fields. We aimed to determine if and how soil microbial properties reliably respond to management, and how these properties indicate long-term changes in soil health, carbon (C) sequestration, and crop yield. We found that reducing tillage increases microbial activity as much as $50 \%$ in upper soil layers and stratifies both bacteria and fungi by depth. Higher cropping intensity (reduced fallow) increases $C$ storage, microbial activity, and biomass, and particularly fungal biomass, which can be three times greater under continuous wheat than wheat-fallow. Chemical and organic fertilizers both increase bacterial biomass, though only organic inputs provide lasting benefits by promoting $\mathrm{C}$ storage and increasing fungal as well as bacterial biomass. We found microbial properties to be sensitive indicators of long-term changes in soil health and productivity, and formed recommendations on appropriate sampling, analysis, and interpretation of microbial data depending on the system studied.
\end{abstract}

Keywords: bacteria; fungi; semiarid; SOC; soil health; soil microbiota; sustainable intensification; wheat

\section{Introduction}

Semiarid grain agriculture represents our most important crops in our most vulnerable landscapes and must respond to the dual pressures of climate change and population growth. Cereal grains make up the majority of world cropland and fertilizer use. Wheat in particular accounts for one-fifth of the global food supply, and demand is expected to increase $31 \%$ by 2050 [1-3]. Marginal lands (arid and semiarid) account for $36 \%$ of global agriculture and support about one-third of the world's population [4]. More marginal land will come under cultivation as the world population grows, despite the fact that nearly one-third of the world's arable land has already been lost to erosion due to unsustainable farming practices $[2,5]$. Wheat agroecosystems are especially vulnerable to a changing climate; about half of wheat is produced in semiarid climates, and yields are expected to decline $5-6 \%$ per $1{ }^{\circ} \mathrm{C}$ temperature rise [6-8]. Degraded soils create a cycle of rising input expenses, decreasing yields, and eventual farmland abandonment that pushes farmers and researchers to search for regenerative options.

Soil microorganisms are critical for sustainable and resilient food production. These organisms regulate plant growth, nutrient availability, erosion, water infiltration and retention, and carbon (C) cycling [9-13]. Soils with abundant and diverse microbial life can better adapt to variable conditions including flood and drought, creating food systems that are resilient in the face of climate change $[2,14,15]$. Since soil structure and composition can 
take years or decades to change in semiarid climates, identifying soil microbial properties that indicate longer-term soil health improvement can guide efforts to protect soils and feed a growing population $[16,17]$.

In order to determine how management practices in semiarid wheat agriculture impact the soil microbial community, we reviewed the literature for studies measuring the effects of different practices on direct measures of the microbial community (e.g., soil microbial abundance, diversity, and activity). We did not consider measures of microbially mediated processes (e.g., soil respiration and carbon mineralization), which are more difficult to interpret [16]. We determined if and how soil microbial properties reliably respond to management changes in semiarid wheat agriculture and addressed the following questions: (1) Are there management practices that consistently support microbial soil health in semiarid wheat agriculture? and (2) How can microbial analyses be used to indicate trends in soil health and crop yield? We organized our findings into sections based on whether management involved changes in tillage, fertilization, or cropping system. Lastly, we included recommendations on which microbial analyses and sampling methods are best suited to detect soil health change in different systems. Understanding how microbial properties indicate and respond to changing soil health can guide efforts to sustain these climate-sensitive agricultural regions.

\section{Methods}

In July 2020, we performed a Web of Knowledge v5.35 search across all databases using the search terms: (micro * OR bacter * OR fung *) AND (semi\$arid OR dryland) AND (soil) AND (farm OR agriculture) AND (manage * OR compost OR cover crop * OR till * OR crop rotat * OR polyculture) AND (wheat) over the years 2000-2020. This search returned 460 results, which were pruned based on the following criteria: (1) compared at least two non-irrigated wheat fields in close proximity to each other under different management strategies, (2) collected at least one direct measure of the soil microbial community (excluding microbial pathogen data), and (3) occurred in areas with 250-600 mm average annual precipitation (excluding Mediterranean climates, where mild, wet winters create distinctive plant growth and soil characteristics). Areas with $>500 \mathrm{~mm}$ precipitation may still be considered semiarid if potential evapotranspiration is more than double precipitation [18], and therefore we included studies up to $600 \mathrm{~mm}$ precipitation that self-identified as semiarid or dryland. For every study we collected information on management type, duration of management type, country, sampling depth, and types of microbial analyses (Supplemental Table S1).

\section{Results and Discussion}

The 460 resulting studies from the Web of Knowledge search were narrowed to 57 based on the three criteria. Studies were distributed over seven countries with most studies taking place in the US and China (Figure 1). Similar numbers of studies fell into each of the three management categories, but there was an uneven distribution of management based on country. Management systems had been established for a median of 8 years, ranging from 4 months to 37 years. Microbial biomass was the most common microbial measurement, and was mostly measured by chloroform fumigation, substrateinduced respiration, or phospholipid fatty acid analysis (PLFA) (Figure 2). PLFA also provided data on microbial community composition and fungi:bacteria ratio (F:B). Microbial activity was mostly measured by enzyme analysis. Further information is included in Supplemental Table S1.

\subsection{Tillage and Residue Management}

The reviewed papers included studies on no-till, changes in tillage frequency or intensity, crop stubble management, and plastic film mulching. No-till agriculture has expanded rapidly in recent decades as a way to improve soil health and reduce erosion. Research has found that reducing tillage in wheat systems can support soil microbes, sequester $\mathrm{C}$, 
build soil structure, reduce vulnerability to drought, and increase profits [19-21]. No-till is especially important in wheat-fallow systems, where conventionally tilled land erodes 5-10 times faster than no-till and 100 times faster than the rate of soil formation [2,22]. Intensively tilled Wyoming wheat-fallow systems have lost $63 \%$ of their native soil organic carbon (SOC) [23].

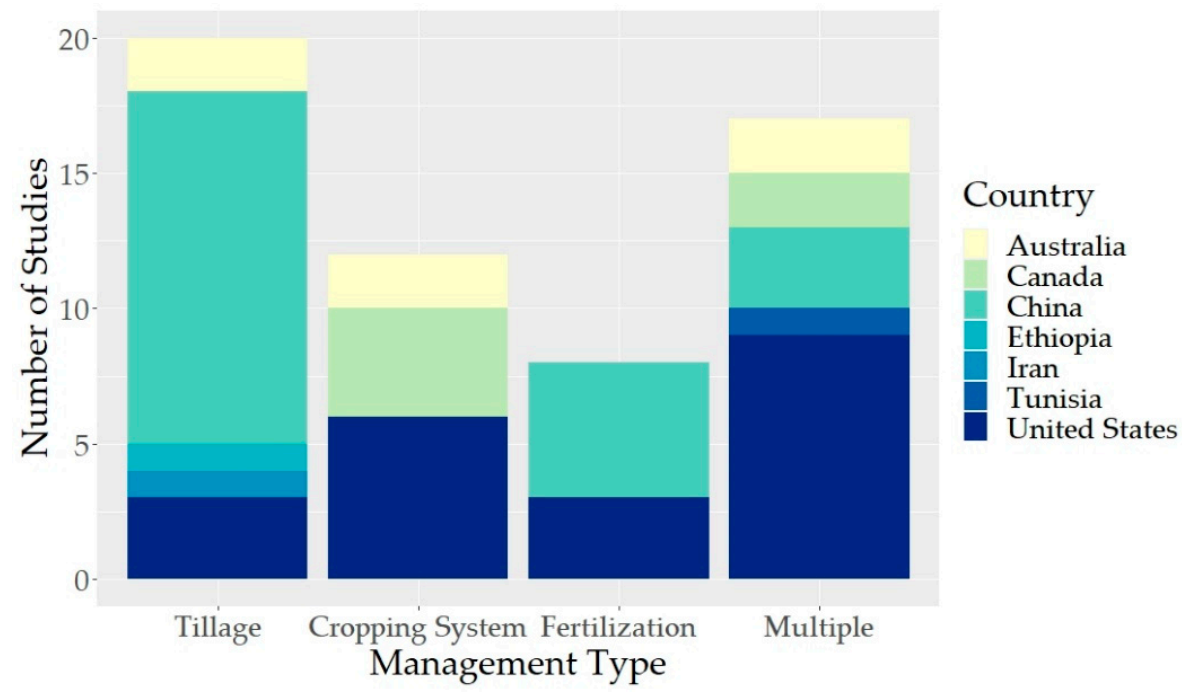

Figure 1. Number of reviewed studies by management type and country.

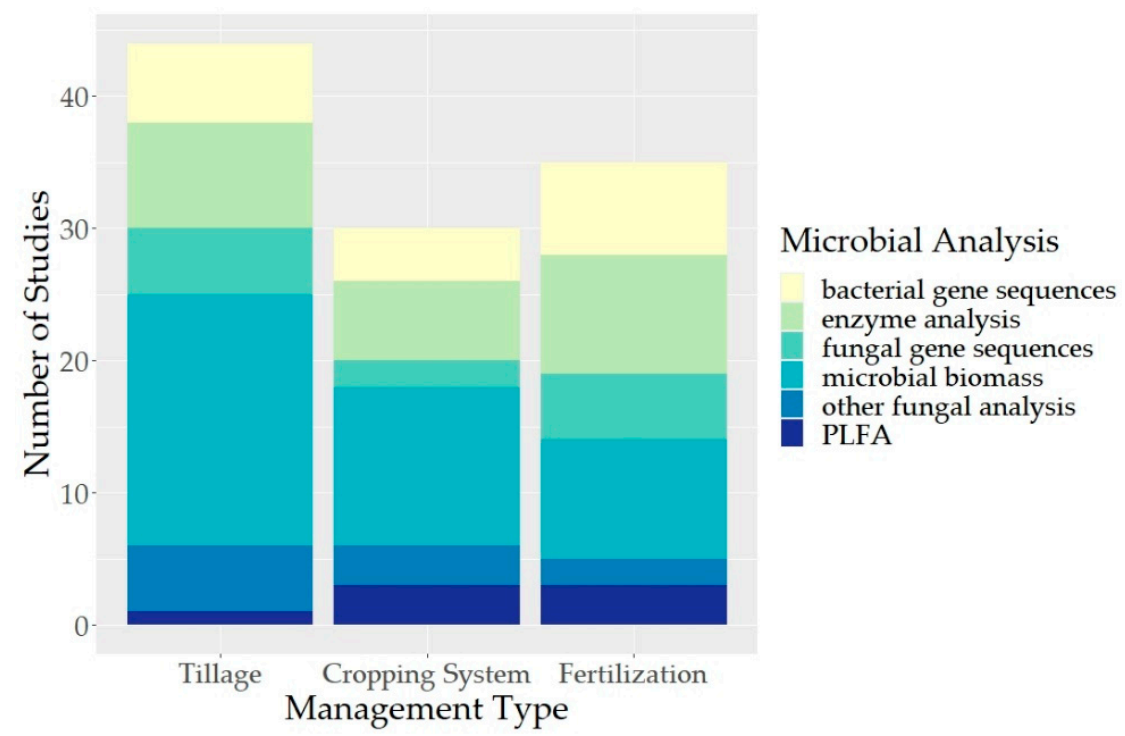

Figure 2. Number of reviewed studies by management type and type of microbial analysis. Many studies included more than one type of management strategy and/or microbial analysis. Only the most common analyses are shown. Other fungal analysis includes arbuscular mycorrhizal fungi (AMF) root colonization, glomalin extraction, and enzyme-linked immunosorbent assay (ELISA). PLFA stands for phospholipid fatty acid analysis.

Reducing tillage in semiarid wheat tended to increase microbial abundance near the soil surface [24-35]. Rhizosphere communities were affected less than bulk soil communities [36], though tillage can still significantly change rhizosphere bacterial diversity and composition [37]. One study in particular found that conversion to no-till increased the activities of four enzymes, microbial biomass carbon and nitrogen (MBC and MBN) (from 211 to $297 \mathrm{mg} / \mathrm{g}$ and 12 to $19 \mathrm{mg} / \mathrm{g}$, respectively), and SOC (from 7.2 to $9.0 \mathrm{~g} / \mathrm{kg}$ ) in the $0-10 \mathrm{~cm}$ soil layer after 15 years, which may have been related to the observed $20 \%$ increase in wheat yield [29]. In contrast, Bissett et al. [38] found no evidence of major benefits after 
20 years of no-till on microbial biomass or enzyme activity, possibly because of functional redundancy in the microbial community or because samples were taken too deep $(0-15 \mathrm{~cm})$ and masked changes closer to the soil surface. Additionally, higher microbial activity or biomass does not always indicate improved soil health, since disturbance can promote mineralization of stored SOC and increase microbial properties in the short-term [39]. For example, Sainju et al. [27] found that reduced tillage decreased estimated nitrogen (N) losses, residue $\mathrm{N}$ mineralization, and $\mathrm{MBN}$ at $0-20 \mathrm{~cm}$.

Untilled fields better retained moisture and regulated temperature [40], which benefits soil microorganisms. Leaving crop stubble on the soil surface further insulates the soil and is therefore particularly important for microbial benefits, according to several studies in Northwest China and Ethiopia [30,33-35]. Compared to straw removal or burning, straw mulching increased MBC and enzyme activities [41-45]. However, yield effects varied; straw decomposition immobilizes $\mathrm{N}$, and these systems therefore require $\mathrm{N}$-rich fertilizers for optimal plant growth. Two studies in China found that plastic film mulching (growing crops through holes in a thin sheet of plastic covering the soil) can increase soil bacterial diversity and arbuscular mycorrhizal fungi (AMF) colonization of wheat, most likely due to increased soil moisture and temperature, but this practice may decrease SOC $[46,47]$.

Reducing tillage also promoted stratification of microorganisms by depth. Studies that sampled multiple depths found that no-till benefits to MBC, MBN, SOC, enzymes, and nutrients (compared with tilled fields) did not extend below 10 or $15 \mathrm{~cm}$ even after up to 22 years, and many found that effects were most apparent at 0-5 cm [28-32]. This data leaves questions as to how no-till affects overall $C$ sequestration throughout the soil profile. However, two Mediterranean wheat studies suggest that stratification of both microbial activity and stored $\mathrm{C}$ in no-till wheat indicates improved soil quality, since surface SOC is essential to soil functions including erosion control, conservation of nutrients, and water infiltration $[48,49]$.

Fungi also stratify by depth in no-till fields, but they may take many years to respond to changes in tillage practices [50]. After four years, Schlatter et al. [51,52] found only weak effects of tillage on fungal or bacterial community composition or diversity. After 12 years, Caesar-TonThat et al. [53] found that tillage reduced fungal glomalin and soil aggregation. Sharma-Poudyal et al. [54] found higher fungal abundance, richness, and diversity with no-till, though a large proportion of fungal groups were not affected by tillage and may act as niche generalists that can feed on both intact and tilled decaying matter. Based on an irrigated wheat study, Sun et al. [55] suggest that tillage affects fungal communities more than bacterial.

\subsection{Cropping Systems}

Use of different cropping systems was the least studied management practice in semiarid wheat fields, and included studies on cropping intensity (fallow frequency), cover cropping, and/or crop rotation. In semiarid regions, wheat systems often include a year of fallow between crops, which allows accumulation of soil water and reduces crop failure due to drought. However, maintaining fallow requires heavy tillage or herbicide use and inefficiently stores water. Only as little as $20 \%$ of precipitation during fallow periods is held for later crop use, while the rest is lost to evaporation and runoff [56,57]. Fallow periods also deplete SOC and have a high potential for erosion $[56,58]$.

The reviewed studies found that increased cropping intensity consistently increased soil microbial biomass and activity, particularly of fungi. Six studies found that reducing fallow frequency or growing cover crops in wheat-fallow systems increased microbial activity and labile $C$ pools, especially in no-till systems [59-62]. Two of these studies found that including fallow every third year (instead of every other) increased MBC, MBN, enzyme activities, and F:B, and in drier areas, may provide as many benefits as eliminating fallow entirely [63,64]. Most convincingly, Rosenzweig et al. [65] compared 96 dryland no-till wheat fields in the semiarid Great Plains and found that increased cropping intensity was associated with higher SOC, aggregate stability, F:B, and fungal 
biomass, and that these effects were robust across variable climates, management histories, and soil types. In continuous rotations compared with wheat-fallow, SOC increased 17\% (from $1.09 \%$ to $1.28 \%$ ), microbial biomass (based on PLFA) increased 35\%, fungal biomass tripled (from 8 to $24 \mathrm{ng} / \mathrm{g}$ ), and aggregate stability doubled. Their analyses demonstrate that reducing fallow can meaningfully improve soil health in these systems by supporting fungi, which enhance soil aggregation and therefore protect SOC from decomposition.

Most cover crop and crop rotation research in semiarid wheat has focused on incorporating legumes, which build soil $\mathrm{N}$ and increase microbial activity, especially when cropping intensity also increases. Rotating wheat with a legume can increase MBC and other labile $C$ pools, $C$ use efficiency, enzyme activity, and especially MBN [66-68]. One study in particular found roughly a doubling of microbial responses, including bacteria number, enzyme activities, fungal biomass, MBC and MBN after six years of replacing fallow with a legume; MBC and MBN increased from 242 to $407 \mathrm{mg} / \mathrm{kg}$ and from 33.7 to $64.5 \mathrm{mg} / \mathrm{g}$, respectively [69]. Molecular studies found that legumes can modify the rhizosphere community in a subsequent wheat crop and increase specific growth-promoting microbes. These effects were probably due to increased $\mathrm{N}$ availability, and depended on adequate moisture [70-72]. Legumes do not seem to affect AMF colonization in a subsequent wheat crop, and may instead host a different community of AMF [73]. A single legume crop can increase soil nutrients and wheat yields for at least 3-4 years in semiarid climates, unlike in wetter climates where effects may persist less than a year $[73,74]$.

Wheat agriculture often displaces semiarid grassland ecosystems that support exceptionally high SOC and microbial activity, encouraging researchers to search for crops that mimic perennial prairie $[23,75,76]$. Notably, the bacterial-based soil food webs under wheat agriculture are less resistant or adaptable to climate change and drought than the fungal-based soil food webs under grasslands [75]. Kernza, a perennial alternative to wheat harvested from a cultivar of intermediate wheatgrass, has been under development for several decades, and is currently grown on 2025 acres across the US [77]. Perennial crops such as Kernza hold promise for drastically reducing soil disturbance and fallow in wheat agroecosystems.

\subsection{Fertilization and Amendment}

The reviewed studies looked at both chemical fertilizers (mainly $\mathrm{N}$ and $\mathrm{P}$ fertilizers) and organic matter amendments (mainly compost, manure, straw mulch, and biosolids). Though fertilization is not always cost-effective for semiarid wheat due to low potential yield, it is still common. Organic matter amendments, frequently used in certified organic systems, consistently support soil microbes and SOC accumulation, but their viability depends on fluctuating price premiums for organic wheat [78].

The soil bacterial community is mainly driven by nutrient status and is especially influenced by chemical fertilizers. Chemical N fertilizers increased SOC, MBC, MBN, and soil bacterial diversity, and altered soil bacterial community structure $[61,79,80]$, with N-cycling microbes increasing disproportionately [79]. In N-limited environments, fertilization increases bacteria more than fungi, lowering C:N and F:B [81,82]. However, competition between plants and microbes may offset fertilizer's effects on microbes [83]. For example, Hamel et al. [83] found that reducing fertilizer inputs did not affect microbial biomass or most fatty acid methyl ester (FAME) biomarkers, possibly because lower plant growth correlated with higher soil moisture. DNA sequencing studies on wheat in other climates have found that $\mathrm{N}$ fertilizer application reduces $\mathrm{N}$-fixing bacteria and alters $\mathrm{N}$-fixer community structure $[84,85]$. Similarly, a semiarid wheat study found more N-fixing genera in unfertilized organic plots than in fertilized or grazed plots [86].

Organic matter inputs significantly influence fungi as well as bacteria and have longlasting effects in semiarid environments where decomposition is slow. Manure increased microbial biomass and activity and soil AMF biomarkers compared with unfertilized plots or plots with chemical fertilizers applied at the same nutrient rate [82,87]. Compost and manure can increase fungal and bacterial abundance, enzyme activity, and SOC, and 
alter fungal community structure [87-89]. In drier environments, effects may persist even 16 years after a one-time application of compost [89]. Biosolids can increase MBC, MBN, microbial diversity, F:B, and SOC, and shift fungal community composition, and these effects can persist years after application $[51,90,91]$. Zhao et al. [45] found that straw mulch had larger effects on MBC and soil structure, while manure had larger effects on SOC. A combination of manure or chemical fertilizer with straw can improve SOC, MBC, enzyme activity, AMF spore density, glomalin, and AMF diversity [45,92].

\subsection{Microbes as Sensitive Indicators}

Microbial properties reliably respond to management changes in semiarid wheat agriculture and are predictive of long-term changes in soil health and crop yield. The reviewed studies frequently found that microbial analyses predicted other changes in soil health such as SOC, aggregation, and sometimes yield often years before these changes were directly significant. Microbial properties that most reliably indicated soil health change in the reviewed studies include microbial biomass, fungal biomass, and F:B (generally by PLFA), enzyme activity, and glomalin concentration. Indicators such as microbial biomass and enzyme activities were able to discriminate among management systems before changes in SOC were detectable and have been called an "early warning system" [29,64]. Microbial community structure and diversity, while sensitive to management, is not easily interpretable, as there is no "ideal" soil microbial community [16,93]. Bierderbeck et al. [69] found that bacteria count and arylsulfatase activity were the most sensitive microbial indicators between cropping systems (wheat-fallow or wheat-legume), though all microbial indicators measured showed significant difference after six years and were more sensitive than physical and chemical soil properties. Araya et al. [33] found higher MBC after only a year of conservation tillage, despite the fact that no other assessed soil chemical parameter was significantly different between systems, and two years before significant yield improvement. Rosenzweig et al. [65] found that fungal biomass and F:B were sensitive indicators of cropping system change and C storage, as small SOC increases correlated with larger increases in fungi. These indicators are especially important in semiarid regions, where soil properties can take a decade or longer to respond to changes in management $[17,20]$.

\subsection{Recommendations for Sampling and Analyses}

Though microbial properties respond to changes in management, choosing the appropriate property to analyze and deciding how to interpret change is challenging, and depends on the system studied. Changes in tillage, fertilization, and cropping system affect microbial properties in different ways and require different sampling methods (Table 1). Management systems may only affect some soil layers, microbial groups, or time periods, and not all microbial properties indicate soil health improvement. Though microbial properties are responsive, they may vary as much or more among seasons or years as among management systems, especially when soil moisture or temperature vary $[38,46,83,86,92]$. Therefore, whenever possible, microbial indicators should be considered in relation to a nearby reference system considered "healthy" based on the research objectives.

Long-term experiments or experiments concerning land use change can focus on fungal properties (using methods such as PLFA, glomalin extraction, or analysis of AMF root colonization) as more reliable soil health indicators or when SOC is particularly relevant, whereas experiments less than five years or based on soil nutrient differences should rely on bacterial indicators and labile $C$ pools.

In general, soil fungal communities are much more stable over time than bacterial communities, which can change drastically across seasons [94]. Fungi can protect organic matter from decomposition by enhancing aggregation and may more accurately indicate SOC accrual due to cropping system change $[65,95]$. Vries and Wallenstein have suggested that fungal hyphae are crucial for maintaining an adaptable, resilient rhizosphere by connecting it to the bulk soil network [13]. Studies on both dryland and irrigated wheat, as well as semiarid grassland, have shown that bacteria and enzyme activities are more 
sensitive to fertilization, while fungi are more sensitive to plant community and growth and to SOC $[82,94,96,97]$.

Table 1. Sampling recommendations for the different management systems reviewed in this paper.

\begin{tabular}{|c|c|}
\hline Study Type & Sampling Recommendation \\
\hline Tillage and Residue Management & $\begin{array}{l}\text { Sample at multiple depths to detect changes in microbial } \\
\text { stratification. Changes in tillage may only affect surface }(0-5 \text {, } \\
10 \text {, or } 15 \mathrm{~cm}) \text { soil layers, or may affect stratification but not } \\
\text { overall microbial abundance or activity. }\end{array}$ \\
\hline Cropping System & $\begin{array}{l}\text { Analyze fungi for a more reliable indicator of increasing soil } \\
\text { organic carbon (SOC). Fungi are more sensitive to plant } \\
\text { dynamics than bacteria and mediate increases in SOC due to } \\
\text { changes in cropping. } \\
\text { Monitor soil moisture, as increased cropping intensity may not } \\
\text { have the desired effect if soil water is depleted. }\end{array}$ \\
\hline Fertilization and Amendment & $\begin{array}{l}\text { Analyze fungi and bacteria separately. Bacteria are more } \\
\text { sensitive to nutrient status than fungi, but a brief abundance in } \\
\mathrm{N} \text {-cycling bacteria and reduction in F:B does not indicate } \\
\text { long-term soil health improvement. }\end{array}$ \\
\hline General & $\begin{array}{l}\text { Avoid sampling immediately after a disturbance that may } \\
\text { cause a short-term spikes in microbial activity, such as } \\
\text { fertilization or tillage. } \\
\text { Whenever possible, microbial properties should be considered } \\
\text { in relation to a nearby reference system considered "healthy" } \\
\text { based on the research objectives, to account for seasonal and } \\
\text { year-to-year variations in microbial activity due to short-term } \\
\text { changes in soil moisture or other factors. } \\
\text { Longer-term experiments or when SOC change is particularly } \\
\text { relevant may choose to focus on fungal properties as more } \\
\text { reliable, stable soil health indicators, whereas experiments less } \\
\text { than five years or based mostly on soil nutrient differences may } \\
\text { need to rely on bacterial properties and labile C pools. }\end{array}$ \\
\hline
\end{tabular}

\section{Conclusions}

\subsection{Summary of Findings}

Reduced tillage, increased cropping intensity, and organic matter inputs consistently support soil microbial health. In addition to preventing the loss of microbe-rich topsoil through erosion, reducing tillage increases microbial biomass and activity in the top 10 or $15 \mathrm{~cm}$, in part due to better temperature and moisture regulation in untilled soil, and also by stratifying both bacteria and fungi by depth. Fungi may be a more accurate indicator of soil health change than bacteria, but require longer to recover after transition to no-till.

Increased cropping intensity (reduced fallow) improves SOC, microbial activity, and fungi. Moreover, fungi are particularly reliable indicators of increasing $C$ storage due to changes in cropping system. Legumes, particularly when they replace fallow, increase microbial activity and especially microbial groups associated with $\mathrm{N}$ fixation and cycling. These effects can last several years, likely due to higher soil nutrients.

Fertilizers generally increase bacterial activity and can lower F:B in N-limited environments. However, organic matter inputs also provide long-term benefit to soil health by increasing SOC and fungal as well as bacterial biomass. The impact of organic fertilizers on microbial activity is long-lasting in semiarid environments where decomposition is slow. Straw mulching is a good option for improving microbial soil health if combined with an N-rich fertilizer.

Microbial properties can be used to reliably indicate soil health change in semiarid wheat agroecosystems, as long as the sampling methods, analyses, and interpretations are appropriate for the system studied. Recommendations for which analyses to use and how to interpret them are summarized in Table 1. 


\subsection{Future Research}

Numerous microbial properties are sensitive to change, but there are still gaps in guidelines as to how analyses indicate long-term change in different systems. Future research can address that gap with long-term agricultural experiments that link short-term microbial change to long-term yield and SOC change. Overall, we hope that clarifying our understanding of soil microbes in semiarid grain agriculture will produce insights that can guide farmers and researchers in sustaining the agricultural productivity of these regions.

Supplementary Materials: The following are available online at https: / www.mdpi.com/article/ 10.3390/agronomy11050852/s1, Table S1: Information on country, management practices studied, microbial analysis, duration, and sampling depth for each study included in the review.

Author Contributions: Conceptualization and methodology, all; data curation, writing-original draft preparation, and visualization, H.R.R.; writing-review and editing, all. All authors have read and agreed to the published version of the manuscript.

Funding: This research was funded by a National Science Foundation Graduate Research Fellowships Program grant \#1003588q and by the University of Wyoming Department of Ecosystems Science \& Management.

Institutional Review Board Statement: Not applicable.

Informed Consent Statement: Not applicable.

Conflicts of Interest: The authors declare no conflict of interest.

\section{References}

1. FAO. World Food and Agriculture: Statistical Pocketbook 2018; FAO: Rome, Italy, 2018; ISBN 978-92-5-131012-0.

2. Intergovernmental Panel on Climate Change (IPCC). Summary for Policymakers. In Climate Change and Land: An IPCC special report on climate change, desertification, land degradation, sustainable land management, food security, and greenhouse gas fluxes in terrestrial ecosystems; Shukla, P.R., Skea, J., Calvo Buendia, E., Masson-Delmotte, V., Pörtner, H.-O., Roberts, D.C., Zhai, P., Slade, R., Connors, S., van Diemen, R., et al., Eds.; IPCC: Geneva, Switzerland, 2019.

3. Shiferaw, B.; Smale, M.; Braun, H.-J.; Duveiller, E.; Reynolds, M.; Muricho, G. Crops That Feed the World 10. Past Successes and Future Challenges to the Role Played by Wheat in Global Food Security. Food Secur. 2013, 5, 291-317. [CrossRef]

4. Wood, S.; Sebastian, K.; Scherr, S.J. Pilot Analysis of Global Ecosystems: Agroecosystems; World Resources Institute: Washington, DC, USA, 2000; ISBN 978-1-56973-457-5.

5. Pimentel, D.; Burgess, M. Soil erosion threatens food production. Agriculture 2013, 3, 443-463. [CrossRef]

6. $\quad$ Asseng, S.; Ewert, F.; Martre, P.; Rötter, R.P.; Lobell, D.B.; Cammarano, D.; Kimball, B.A.; Ottman, M.J.; Wall, G.W.; White, J.W.; et al. Rising temperatures reduce global wheat production. Nat. Clim. Chang. 2015, 5, 143-147. [CrossRef]

7. Fischer, T.; Byerlee, D.; Edmeades, G. Crop yields and food security: Will yield increases continue to feed the world? Capturing oppor. Overcoming obstacles Australian agronomy. In Proceedings of the 16th Australian Agronomy Conference 2012, Armidale, NSW, Australia, 14-18 October 2012.

8. O'Leary, G.J.; Aggarwal, P.K.; Calderini, D.F.; Connor, D.J.; Craufurd, P.; Eigenbrode, S.D.; Han, X.; Hatfield, J.L. Challenges and responses to ongoing and projected climate change for dryland cereal production systems throughout the world. Agronomy 2018, 8, 34. [CrossRef]

9. Adhya, T.K.; Kumar, N.; Reddy, G.; Podile, A.R.; Bee, H.; Samantaray, B. Microbial mobilization of soil phosphorus and sustainable p management in agricultural soils. Curr. Sci. 2015, 108, 1280-1287.

10. Bender, S.F.; Wagg, C.; van der Heijden, M.G.A. An underground revolution: Biodiversity and soil ecological engineering for agricultural sustainability. Trends Ecol. Evol. 2016, 31, 440-452. [CrossRef]

11. Bhattacharyya, P.N.; Goswami, M.P.; Bhattacharyya, L.H. Perspective of beneficial microbes in agriculture under changing climatic scenario: A review. J. Phytol. 2016, 26-41. [CrossRef]

12. Reali, C.; Pilz Júnior, H.L.; Meile, J.C.; Galindo, S.S.; Fiuza, L.M.; Reali, C.; Pilz Júnior, H.L.; Meile, J.C.; Galindo, S.S.; Fiuza, L.M. Functional genes of microorganisms, comprehending the dynamics of agricultural ecosystems. Braz. Arch. Biol. Technol. 2017, 60. [CrossRef]

13. de Vries, F.T.; Wallenstein, M.D. Below-ground connections underlying above-ground food production: A framework for optimising ecological connections in the rhizosphere. J. Ecol. 2017, 105, 913-920. [CrossRef]

14. Mendes, R.; Garbeva, P.; Raaijmakers, J.M. The rhizosphere microbiome: Significance of plant beneficial, plant pathogenic, and human pathogenic microorganisms. FEMS Microbiol. Rev. 2013, 37, 634-663. [CrossRef]

15. Sharma, S.B.; Sayyed, R.Z.; Trivedi, M.H.; Gobi, T.A. Phosphate solubilizing microbes: Sustainable approach for managing phosphorus deficiency in agricultural soils. SpringerPlus 2013, 2, 587. [CrossRef] [PubMed] 
16. Fierer, N.; Wood, S.A.; de Mesquita, C.P.B. How microbes can, and cannot, be used to assess soil health. Soil Biol. Biochem. 2021, 153, 108111. [CrossRef]

17. Stott, D. Recommended Soil Health Indicators and Associated Laboratory Procedures; U.S. Department of Agriculture, Natural Resources Conservation Service: Washington, DC, USA, 2019; p. 76.

18. Huang, J.; Ji, M.; Xie, Y.; Wang, S.; He, Y.; Ran, J. Global semi-arid climate change over last 60 years. Clim. Dyn. 2016, 3-4, 1131-1150. [CrossRef]

19. Derpsch, R.; Friedrich, T.; Kassam, A.; Li, H. Current status of adoption of no-till farming in the world and some of its main benefits. Int. J. Agric. Biol. Eng. 2010, 3, 1-25. [CrossRef]

20. Ghimire, R.; Norton, J.B.; Norton, U.; Ritten, J.P.; Stahl, P.D.; Krall, J.M. Long-term farming systems research in the central high plains. Renew. Agric. Food Syst. 2013, 28, 183-193. [CrossRef]

21. Varner, B.T.; Epplin, F.M.; Strickland, G.L. Economics of no-till versus tilled dryland cotton, grain sorghum, and wheat. Agron. J. 2011, 103, 1329-1338. [CrossRef]

22. Sharratt, B.S.; Kennedy, A.C.; Hansen, J.C.; Schillinger, W.F. Soil carbon loss by wind erosion of summer fallow fields in washington's dryland wheat region. Soil Sci. Soc. Am. J. 2018, 82, 1551-1558. [CrossRef]

23. Norton, J.; Mukhwana, E.; Norton, U. Loss and recovery of soil organic carbon and nitrogen in a semiarid agroecosystem. Soil Sci. Soc. Am. J. 2012, 76, 505. [CrossRef]

24. Chen, H.; Bai, Y.; Wang, Q.; Chen, F.; Li, H.; Tullberg, J.N.; Murray, J.R.; Gao, H.; Gong, Y. Traffic and tillage effects on wheat production on the loess plateau of china: 1. crop yield and som. Soil Res. 2008, 46, 645-651. [CrossRef]

25. Hoyle, F.C.; Murphy, D.V. Influence of organic residues and soil incorporation on temporal measures of microbial biomass and plant available nitrogen. Plant Soil 2011, 347, 53. [CrossRef]

26. Mohammadi, K.; Rokhzadi, A.; Saberali, S.F.; Byzedi, M.; Nezhad, M.T.K. Tillage effects on soil properties and wheat cultivars traits. Arch. Agron. Soil Sci. 2013, 59, 1625-1641. [CrossRef]

27. Sainju, U.M.; Caesar-Tonthat, T.; Lenssen, A.W.; Evans, R.G.; Kolberg, R. Tillage and cropping sequence impacts on nitrogen cycling in dryland farming in eastern Montana, USA. Soil Tillage Res. 2009, 103, 332-341. [CrossRef]

28. Liu, E.; Teclemariam, S.G.; Yan, C.; Yu, J.; Gu, R.; Liu, S.; He, W.; Liu, Q. Long-term effects of no-tillage management practice on soil organic carbon and its fractions in the northern China. Geoderma 2014, 213, 379-384. [CrossRef]

29. Liu, E.K.; Zhao, B.Q.; Mei, X.R.; So, H.B.; Li, J.; Li, X.Y. Effects of no-tillage management on soil biochemical characteristics in northern China. J. Agric. Sci. 2010, 148, 217. [CrossRef]

30. Liu, Y.; Yang, L.; Gu, D.; Wu, W.; Wen, X.; Liao, Y. Influence of tillage practice on soil $\mathrm{CO}_{2}$ emission rate and soil characteristics in a dryland wheat field. Int. J. Agric. Biol. Pak. 2013, 15, 680-686.

31. Wang, Q.; Bai, Y.; Gao, H.; He, J.; Chen, H.; Chesney, R.C.; Kuhn, N.J.; Li, H. Soil chemical properties and microbial biomass after 16 years of no-tillage farming on the loess plateau, China. Geoderma 2008, 144, 502-508. [CrossRef]

32. Zhang, H.; Zhang, Y.; Yan, C.; Liu, E.; Chen, B. Soil Nitrogen and its fractions between long-term conventional and no-tillage systems with straw retention in dryland farming in northern China. Geoderma 2016, 269, 138-144. [CrossRef]

33. Araya, T.; Nyssen, J.; Govaerts, B.; Deckers, J.; Sommer, R.; Bauer, H.; Gebrehiwot, K.; Cornelis, W.M. seven years resourceconserving agriculture effect on soil quality and crop productivity in the ethiopian drylands. Soil Tillage Res. 2016, 163, 99-109. [CrossRef]

34. Niu, Y.; Zhang, R.; Luo, Z.; Li, L.; Cai, L.; Li, G.; Xie, J. Contributions of Long-Term Tillage systems on crop production and soil properties in the semi-arid loess plateau of China. J. Sci. Food Agric. 2016, 96, 2650-2659. [CrossRef]

35. Yeboah, S.; Zhang, R.; Cai, L.; Li, L.; Xie, J.; Luo, Z.; Liu, J.; Wu, J. tillage effect on soil organic carbon, microbial biomass carbon and crop yield in spring wheat-field pea rotation. Plant Soil Environ. 2016, 62, 279-285. [CrossRef]

36. Yin, C.; Mueth, N.; Hulbert, S.; Schlatter, D.; Paulitz, T.C.; Schroeder, K.; Prescott, A.; Dhingra, A. Bacterial communities on wheat grown under long-term conventional tillage and no-till in the pacific northwest of the United States. Phytobiomes J. 2017, 1, 83-90. [CrossRef]

37. Xia, Q.; Liu, X.; Gao, Z.; Wang, J.; Yang, Z. Responses of rhizosphere soil bacteria to 2-year tillage rotation treatments during fallow period in semiarid southeastern loess plateau. PeerJ 2020, 8, e8853. [CrossRef] [PubMed]

38. Bissett, A.; Richardson, A.E.; Baker, G.; Kirkegaard, J.; Thrall, P.H. Bacterial community response to tillage and nutrient additions in a long-term wheat cropping experiment. Soil Biol. Biochem. 2013, 58, 281-292. [CrossRef]

39. Jackson, L.E.; Calderon, F.J.; Steenwerth, K.L.; Scow, K.M.; Rolston, D.E. Responses of soil microbial processes and community structure to tillage events and implications for soil quality. Geoderma 2003, 114, 305-317. [CrossRef]

40. Coolman, R.M.; Hoyt, G.D. The effects of reduced tillage on the soil environment. HortTechnology 1993, 3, 143-145. [CrossRef]

41. Akhtar, K.; Wang, W.; Khan, A.; Ren, G.; Zaheer, S.; Sial, T.A.; Feng, Y.; Yang, G. Straw mulching with fertilizer nitrogen: An approach for improving crop yield, soil nutrients and enzyme activities. Soil Use Manag. 2019, 35, 526-535. [CrossRef]

42. Hoyle, F.C.; Murphy, D.V.; Fillery, I.R.P. Temperature and stubble management influence microbial $\mathrm{CO}_{2}-\mathrm{C}$ evolution and gross $\mathrm{n}$ transformation rates. Soil Biol. Biochem. 2006, 38, 71-80. [CrossRef]

43. Soon, Y.K.; Lupwayi, N.Z. Straw management in a cold semi-arid region: Impact on soil quality and crop productivity. Field Crop. Res. 2012, 139, 39-46. [CrossRef]

44. Wang, J.; Fu, X.; Sainju, U.M.; Zhao, F. Soil carbon fractions in response to straw mulching in the loess plateau of China. Biol. Fertil. Soils 2018, 54, 423-436. [CrossRef] 
45. Zhao, Y.; Wang, P.; Li, J.; Chen, Y.; Ying, X.; Liu, S. The effects of two organic manures on soil properties and crop yields on a temperate calcareous soil under a wheat-maize cropping system. Eur. J. Agron. 2009, 31, 36-42. [CrossRef]

46. Huang, F.; Liu, Z.; Mou, H.; Li, J.; Zhang, P.; Jia, Z. Impact of farmland mulching practices on the soil bacterial community structure in the semiarid area of the loess plateau in China. Eur. J. Soil Biol. 2019, 92, 8-15. [CrossRef]

47. Liu, Y.; Mao, L.; He, X.; Cheng, G.; Ma, X.; An, L.; Feng, H. Rapid change of am fungal community in a rain-fed wheat field with short-term plastic film mulching practice. Mycorrhiza 2012, 22, 31-39. [CrossRef]

48. Melero, S.; López-Bellido, R.J.; López-Bellido, L.; Muñoz-Romero, V.; Moreno, F.; Murillo, J.M.; Franzluebbers, A.J. Stratification ratios in a rainfed mediterranean vertisol in wheat under different tillage, rotation and $\mathrm{n}$ fertilisation rates. Soil Tillage Res. 2012, 119, 7-12. [CrossRef]

49. Madejón, E.; Moreno, F.; Murillo, J.M.; Pelegrín, F. Soil biochemical response to long-term conservation tillage under semi-arid mediterranean conditions. Soil Tillage Res. 2007, 94, 346-352. [CrossRef]

50. Schlatter, D.C.; Kahl, K.; Carlson, B.; Huggins, D.R.; Paulitz, T. Fungal community composition and diversity vary with soil depth and landscape position in a no-till wheat-based cropping system. FEMS Microbiol. Ecol. 2018, 94. [CrossRef]

51. Schlatter, D.C.; Schillinger, W.F.; Bary, A.I.; Sharratt, B.; Paulitz, T.C. Biosolids and conservation tillage: Impacts on soil fungal communities in dryland wheat-fallow cropping systems. Soil Biol. Biochem. 2017, 115, 556-567. [CrossRef]

52. Schlatter, D.C.; Paul, N.C.; Shah, D.H.; Schillinger, W.F.; Bary, A.I.; Sharratt, B.; Paulitz, T.C. Biosolids and tillage practices influence soil bacterial communities in dryland wheat. Microb. Ecol. 2019, 78, 737-752. [CrossRef]

53. Caesar-TonThat, T.; Sainju, U.M.; Wright, S.F.; Shelver, W.L.; Kolberg, R.L.; West, M. Long-term tillage and cropping effects on microbiological properties associated with aggregation in a semi-arid soil. Biol. Fertil. Soils 2011, 47, 157-165. [CrossRef]

54. Sharma-Poudyal, D.; Schlatter, D.; Yin, C.; Hulbert, S.; Paulitz, T. Long-term no-till: A major driver of fungal communities in dryland wheat cropping systems. PLoS ONE 2017, 12, e0184611. [CrossRef]

55. Sun, R.; Li, W.; Dong, W.; Tian, Y.; Hu, C.; Liu, B. Tillage changes vertical distribution of soil bacterial and fungal communities. Front. Microbiol. 2018, 9. [CrossRef]

56. Kaur, G.; Garcia, A.G.Y.; Norton, U.; Persson, T.; Kelleners, T. Effects of cropping practices on water-use and water productivity of dryland winter wheat in the high plains ecoregion of wyoming. J. Crop Improv. 2015, 29, 491-517. [CrossRef]

57. Nielsen, D.C.; Vigil, M.F. Precipitation storage efficiency during fallow in wheat-fallow systems. Agron. J. 2010, 102, 537-543. [CrossRef]

58. Norton, J.B. No-till Grain Production in Wyoming: Status and Potential. In Proceedings of the Western Nutrient Management Conference, Salt Lake City, UT, USA, 8-9 March 2007; Volume 7, p. 6.

59. Calderón, F.J.; Nielsen, D.; Acosta-martínez, V.; Vigil, M.F.; Lyon, D. Cover crop and irrigation effects on soil microbial communities and enzymes in semiarid agroecosystems of the central great plains of north America. Pedosphere 2016, 26, 192-205. [CrossRef]

60. Frank, A.B.; Liebig, M.A.; Tanaka, D.L. Management effects on soil $\mathrm{CO}_{2}$ efflux in northern Semiarid grassland and cropland. Soil Tillage Res. 2006, 89, 78-85. [CrossRef]

61. Liu, J.; Dai, J.; Wang, Z.; Zhai, B. Effects of fallow or planting wheat (Triticum Aestivum L.) and fertilizing p or fertilizing $\mathrm{p}$ and $\mathrm{n}$ practices on soil carbon and nitrogen in a low-organic-matter Soil. Soil Sci. Plant Nutr. 2016, 62, 263-270. [CrossRef]

62. Sherrod, L.A.; Peterson, G.A.; Westfall, D.G.; Ahuja, L.R. Soil organic carbon pools after 12 years in no-till dryland agroecosystems. Soil Sci. Soc. Am. J. 2005, 69, 1600-1608. [CrossRef]

63. Acosta-Martínez, V.; Mikha, M.M.; Vigil, M.F. Microbial communities and enzyme activities in soils under alternative crop rotations compared to wheat-fallow for the central great plains. Appl. Soil Ecol. 2007, 37, 41-52. [CrossRef]

64. Sainju, U.M.; Lenssen, A.; Caesar-Thonthat, T.; Waddell, J. Dryland plant biomass and soil carbon and nitrogen fractions on transient land as influenced by tillage and crop rotation. Soil Tillage Res. 2007, 93, 452-461. [CrossRef]

65. Rosenzweig, S.T.; Fonte, S.J.; Schipanski, M.E. Intensifying rotations increases soil carbon, fungi, and aggregation in semi-arid agroecosystems. Agric. Ecosyst. Environ. 2018, 258, 14-22. [CrossRef]

66. Doolette, A.; Armstrong, R.; Tang, C.; Guppy, C.; Mason, S.; McNeill, A. Phosphorus uptake benefit for wheat following legume break crops in semi-arid Australian farming systems. Nutr. Cycl. Agroecosystems 2019, 113, 247-266. [CrossRef]

67. O'Dea, J.K.; Jones, C.A.; Zabinski, C.A.; Miller, P.R.; Keren, I.N. Legume, cropping intensity, and n-fertilization effects on soil attributes and processes from an eight-year-old semiarid wheat system. Nutr. Cycl. Agroecosystems 2015, 102, 179-194. [CrossRef]

68. Wachter, J.M.; Painter, K.M.; Carpenter-Boggs, L.A.; Huggins, D.R.; Reganold, J.P. Productivity, economic performance, and soil quality of conventional, mixed, and organic dryland farming systems in eastern Washington State. Agric. Ecosyst. Environ. 2019, 286, UNSP 106665. [CrossRef]

69. Biederbeck, V.O.; Zentner, R.P.; Campbell, C.A. Soil microbial populations and activities as influenced by legume green fallow in a semiarid climate. Soil Biol. Biochem. 2005, 37, 1775-1784. [CrossRef]

70. Bainard, L.D.; Hamel, C.; Gan, Y. Edaphic properties override the influence of crops on the composition of the soil bacterial community in a semiarid agroecosystem. Appl. Soil Ecol. 2016, 105, 160-168. [CrossRef]

71. Hamel, C.; Gan, Y.; Sokolski, S.; Bainard, L.D. High frequency cropping of pulses modifies soil nitrogen level and the rhizosphere bacterial microbiome in 4-year rotation systems of the semiarid prairie. Appl. Soil Ecol. 2018, 126, 47-56. [CrossRef]

72. Yang, C.; Hamel, C.; Gan, Y.; Vujanovic, V. Pyrosequencing reveals how pulses influence rhizobacterial communities with feedback on wheat growth in the semiarid prairie. Plant Soil 2013, 367, 493. [CrossRef] 
73. Kirkegaard, J.A.; Ryan, M.H. Magnitude and mechanisms of persistent crop sequence effects on wheat. Field Crop. Res. 2014, 164, 154-165. [CrossRef]

74. McBeath, T.M.; Gupta, V.V.S.R.; Llewellyn, R.S.; Davoren, C.W.; Whitbread, A.M. Break-crop effects on wheat production across soils and seasons in a semi-arid environment. Crop Pasture Sci. 2015, 66, 566-579. [CrossRef]

75. De Vries, F.T.; Liiri, M.E.; Bjørnlund, L.; Bowker, M.A.; Christensen, S.; Setälä, H.M.; Bardgett, R.D. Land use alters the resistance and resilience of soil food webs to drought. Nat. Clim. Chang. 2012, 2, 276-280. [CrossRef]

76. McKenna, T.P.; Crews, T.E.; Kemp, L.; Sikes, B.A. Community structure of soil fungi in a novel perennial crop monoculture, annual agriculture, and native prairie reconstruction. PLoS ONE 2020, 15, e0228202. [CrossRef] [PubMed]

77. The State of Kernza ${ }^{\circledR}$. Kernza ${ }^{\circledR}$. 2020. Available online: https://kernza.org/watch-the-2020-kernza-meeting/ (accessed on 26 April 2021).

78. Zentner, R.P.; Basnyat, P.; Brandt, S.A.; Thomas, A.G.; Ulrich, D.; Campbell, C.A.; Nagy, C.N.; Frick, B.; Lemke, R.; Malhi, S.S.; et al. Effects of input management and crop diversity on economic returns and riskiness of cropping systems in the semi-arid canadian prairie. Renew. Agric. Food Syst. 2011, 26, 208-223. [CrossRef]

79. Qiu, W.; Liu, J.; Li, B.; Wang, Z. $\mathrm{N}_{2} \mathrm{O}$ and $\mathrm{CO}_{2}$ emissions from a dryland wheat cropping system with long-term $\mathrm{n}$ fertilization and their relationships with soil C, N, and bacterial community. Environ. Sci. Pollut. Res. 2020, 27, 8673-8683. [CrossRef]

80. Wang, R.; Hu, Y.; Wang, Y.; Ali, S.; Liu, Q.; Guo, S. Nitrogen application increases soil respiration but decreases temperature sensitivity: Combined effects of crop and soil properties in a semiarid agroecosystem. Geoderma 2019, 353, 320-330. [CrossRef]

81. Strickland, M.S.; Rousk, J. Considering fungal:bacterial dominance in soils-Methods, controls, and ecosystem implications. Soil Biol. Biochem. 2010, 42, 1385-1395. [CrossRef]

82. Liao, H.; Zhang, Y.; Zuo, Q.; Du, B.; Chen, W.; Wei, D.; Huang, Q. Contrasting responses of bacterial and fungal communities to aggregate-size fractions and long-term fertilizations in soils of northeastern China. Sci. Total Environ. 2018, 635, 784-792. [CrossRef]

83. Hamel, C.; Hanson, K.; Selles, F.; Cruz, A.F.; Lemke, R.; McConkey, B.; Zentner, R. Seasonal and long-term resource-related variations in soil microbial communities in wheat-based rotations of the canadian prairie. Soil Biol. Biochem. 2006, 38, 2104-2116. [CrossRef]

84. Wang, C.; Zheng, M.; Song, W.; Wen, S.; Wang, B.; Zhu, C.; Shen, R. Impact of 25 years of inorganic fertilization on diazotrophic abundance and community structure in an acidic soil in southern China. Soil Biol. Biochem. 2017, 113, 240-249. [CrossRef]

85. Reardon, C.L.; Gollany, H.T.; Wuest, S.B. Diazotroph community structure and abundance in wheat-fallow and wheat-pea crop rotations. Soil Biol. Biochem. 2014, 69, 406-412. [CrossRef]

86. Ishaq, S.L.; Seipel, T.; Yeoman, C.J.; Menalled, F.D. Soil Bacterial communities of wheat vary across the growing season and among dryland farming systems. Geoderma 2020, 358, 113989. [CrossRef]

87. Tautges, N.E.; Sullivan, T.S.; Reardon, C.L.; Burke, I.C. Soil microbial diversity and activity linked to crop yield and quality in a dryland organic wheat production system. Appl. Soil Ecol. 2016, 108, 258-268. [CrossRef]

88. Calderón, F.J.; Vigil, M.F.; Benjamin, J. Compost input effect on dryland wheat and forage yields and soil quality. Pedosphere 2018, 28, 451-462. [CrossRef]

89. Reeve, J.R.; Endelman, J.B.; Miller, B.E.; Hole, D.J. Residual effects of compost on soil quality and dryland wheat yield sixteen years after compost application. Soil Sci. Soc. Am. J. 2012, 76, 278-285. [CrossRef]

90. Bouzaiane, O.; Cherif, H.; Saidi, N.; Jedidi, N.; Hassen, A. Effects of municipal solid waste compost application on the microbial biomass of cultivated and non-cultivated soil in a semi-arid zone. Waste Manag. Res. 2007, 25, 334-342. [CrossRef]

91. Cogger, C.G.; Bary, A.I.; Kennedy, A.C.; Fortuna, A.-M. Long-term crop and soil response to biosolids applications in dryland wheat. J. Environ. Qual. 2013, 42, 1872-1880. [CrossRef] [PubMed]

92. Wu, F.; Dong, M.; Liu, Y.; Ma, X.; An, L.; Young, J.P.W.; Feng, H. Effects of long-term fertilization on am fungal community structure and glomalin-related soil protein in the loess plateau of China. Plant Soil 2011, 342, 233-247. [CrossRef]

93. Fierer, N. Embracing the unknown: Disentangling the complexities of the soil microbiome. Nat. Rev. Microbiol. 2017, 15, 579-590. [CrossRef]

94. Hannula, S.E.; Kielak, A.M.; Steinauer, K.; Huberty, M.; Jongen, R.; Long, J.R.D.; Heinen, R.; Bezemer, T.M. Time after time: Temporal variation in the effects of grass and forb species on soil bacterial and fungal communities. Microbiology 2019, 10. [CrossRef]

95. Frey, S.D. Mycorrhizal fungi as mediators of soil organic matter dynamics. Annu. Rev. Ecol. Evol. Syst. 2019, 50, 237-259. [CrossRef]

96. Ai, C.; Zhang, S.; Zhang, X.; Guo, D.; Zhou, W.; Huang, S. Distinct responses of soil bacterial and fungal communities to changes in fertilization regime and crop rotation. Geoderma 2018, 319, 156-166. [CrossRef]

97. Cassman, N.A.; Leite, M.F.A.; Pan, Y.; de Hollander, M.; van Veen, J.A.; Kuramae, E.E. Plant and soil fungal but not soil bacterial communities are linked in long-term fertilized grassland. Sci. Rep. 2016, 6, 23680. [CrossRef] 